JOANNA STAWIŃSKA

Polska Szkoła Przedmiotów Ojczystych

im. Św. Józefa w Amersham

\title{
ROZWÓJ METOD OPRACOWANIA POLSKICH ZBIORÓW RĘKOPIŚMIENNYCH W ŚWIETLE KATALOGÓW DRUKOWANYCH
}

\section{Wprowadzenie}

W artykule zwrócono uwagę na rolę i możliwość wykorzystania katalogów drukowanych rękopisów polskich bibliotek naukowych ${ }^{1} \mathrm{w}$ badaniach bibliologicznych. Katalogi drukowane rękopisów są źródłem wiedzy o zasobach rękopiśmiennych w bibliotekach. W niniejszym artykule omówiono sposoby tworzenia opisów dokumentów rękopiśmiennych w katalogach drukowanych rękopisów polskich bibliotek naukowych. Zwrócono uwagę na strukturę katalogów oraz przeanalizowano wstępy uczonych tworzących katalogi rękopisów. Rolę tworzenia drukowanych katalogów rękopisów podkreślił po raz pierwszy w piśmiennictwie Karol Buczek. Tematykę tę poruszył na IV Zjeździe Bibliotekarzy Polskich w Warszawie w 1936 roku, stwierdzając:

[...] byłoby zewszechmiar pożądane i celowe zebranie możliwie pełnych i szczegółowych wiadomości o ilościowej i jakościowej zawartości jeśli już nie wszystkich to przynajmniej mniej lub więcej dostępnych zbiorów i opublikowanie tego zestawienia $[\ldots]^{2}$.

${ }^{1}$ Wykaz jednostek rękopiśmiennych, opracowanych według przyjętych zasad (zbiory specjalne), ułożony w określonym porządku, udostępnia czytelnikowi ich zawartość i ułatwia odnalezienie poszukiwania materiałów źródłowych; Encyklopedia wiedzy o książce, red. A. Birkenmajer i in. Wrocław 1971, s. 1134.

${ }^{2} \mathrm{~K}$. Buczek, Zbiory rękopisów polskich bibliotek naukowych (zagadnienia i dezyderaty), oprac. K. Świerkowski [w:] IV Zjazd Bibliotekarzy Polskich w Warszawie. Referaty, cz. 1, Warszawa 1936, s. 79. 
Ponad pół wieku od stworzenia pierwszego katalogu drukowanego rękopisów K. Buczek postulował o powstanie instrukcji katalogowej ułatwiającej tworzenie opisów dokumentów rękopiśmiennych.

W niniejszym opracowaniu przeanalizowano 91 katalogów drukowanych rękopisów polskich bibliotek naukowych ${ }^{3}$, posiadających znaczące kolekcje rękopisów. Pominięto katalogi cząstkowe zawierające niewielki zakres opracowanych rękopisów, znajdujących się w bibliotece. W artykule omówiono katalogi drukowane rękopisów następujących bibliotek naukowych w Polsce: Biblioteki Uniwersytetu Jagiellońskiego w Krakowie, Biblioteki PAU i PAN w Krakowie, Biblioteka Książąt Czartoryskich w Krakowie, Biblioteki PAN w Kórniku, Biblioteki Zakładu Narodowego im. Ossolińskich we Wrocławiu, Biblioteki Uniwersytetu Wrocławskiego oraz Biblioteki Narodowej w Warszawie. Szczególną uwagę poświęcono zbiorom rękopiśmiennym, które zawierają kolekcję ponad 15000 manuskryptów. Problematykę artykułu otwiera omówienie katalogów rękopisów najstarszej biblioteki w Polsce - Biblioteki Uniwersytetu Jagiellońskiego w Krakowie, a rozważania zamyka prezentacja katalogów drukowanych rękopisów Biblioteki Narodowej w Warszawie.

W toku dociekań naukowych zwrócono uwagę na brak w niektórych bibliotekach naukowych katalogów drukowanych rękopisów. Są to następujące instytucje: Wojewódzka i Miejska Biblioteka Publiczna w Bydgoszczy, Książnica Cieszyńska, Biblioteka Śląska w Katowicach, Wojewódzka Biblioteka Publiczna im. J. Piłsudskiego w Łodzi, Biblioteka Główna Uniwersytetu Szczecińskiego oraz Biblioteka Główna Uniwersytetu Mikołaja Kopernika w Toruniu, posiadająca jedynie katalog cząstkowy rękopisów. W opracowaniu przybliżono historyczne projekty stworzenia katalogów rękopisów, które nie doczekały się publikacji ze względu na niedopracowanie i niejednolity sposób opisu rękopisów.

Zakres chronologiczny omawianych katalogów wyznacza powstanie pierwszego katalogu drukowanego rękopisów o znaczeniu naukowym, dzieło Jana Daniela Janockiego - Specimen catalogi codicum manuscriptorum Bibliothecae Zalusciana ${ }^{4}$. Katalog ten zawierał 500 rękopisów, w tym 53 polskie, podzielone według formatów i języków, znajdujących się w Bibliotece Załuskich. Na końcu katalogu zamieszczony był indeks autorów i rzeczy, ułatwia-

${ }^{3}$ Wykaz bibliotek naukowych w Polsce - Ustawa z dnia 27 czerwca 1997 roku o bibliotekach (Dz. U. z 1997 r. Nr 85, poz. 539 z późniejszymi zmianami). Rozporządzenie Ministra Kultury i Dziedzictwa Narodowego z dnia 2 kwietnia 2012 r. w sprawie zasad i trybu zaliczania bibliotek do bibliotek naukowych oraz ustalania ich wykazu (Dz. U. z 2012 r. Nr 0, poz. 390).

${ }^{4}$ Encyklopedia wiedzy o ksiażce, red. A. Birkenmajer, Wrocław 1971, s. 1135. 
jący czytelnikowi poszukiwania interesujących go pozycji. Andrzej Załuski, który sfinansował wydanie katalogu w 1752 roku w Dreźnie, nie wprowadził go na rynek księgarski, lecz ofiarowywał jego egzemplarze członkom domów panujących i wybitnym uczonym. Katalog drukowany rękopisów, który zapoczątkował naukowe opisywanie i publikowanie informacji o zasobach rękopiśmiennych, to katalog rękopisów Biblioteki Uniwersytetu Jagiellońskiego ${ }^{5}$ Władysława Wisłockiego, wydany w Krakowie (1877-1881). Kontynuowany jako Inwentarz Biblioteki Uniwersytetu Jagiellońskiego w latach: 1962, 1963, $1983^{6}$. Datą graniczną omawianych katalogów rękopiśmiennych bibliotek naukowych są współcześnie wydawane katalogi rękopisów do 2012 roku.

\section{Wytyczne opracowania zbiorów rękopiśmiennych - analiza historyczna}

Pierwszym znakiem zainteresowania się badaczy problemem opracowania zbiorów rękopiśmiennych były uwagi prof. Wincentego Zakrzewskiego: Jak należałoby wydawać zbiory listów i aktów historycznych $z$ wieku 16-tgo lub późniejszych ${ }^{7}$. Wytyczne te pośrednio zawierały wskazówki katalogowania zbiorów rękopiśmiennych, jednak artykuł ten dotyczył jedynie niewielkiego zakresu zbiorów rękopiśmiennych (listów i aktów napisanych do XVI w.). Na przestrzeni pół wieku powstały w Polsce zaledwie trzy instrukcje katalogowania zbiorów rękopiśmiennych w polskich bibliotekach naukowych: tj. Wskazówki do inwentaryzacji rękopisów ułożone z polecenia Komisyji Umiejętności przez Adama Chmiela ułożone, wydane w Krakowie w 1903 roku8. Wytyczne opracowywania zbiorów rękopiśmiennych kontynuowane przez

${ }^{5}$ W. Wisłocki, Katalog rękopisów Biblijoteki Uniwersytetu Jagiellońskiego, cz. 1, z. 1-4, Wstęp. Rękopisy 1-1875, Kraków; cz. 2, z. 5-8, Rękopisy 1876-4156. Indeks.

${ }^{6} \mathrm{Nr}$ 4175-6000, Kraków 1938 (mps powiel.); Nr 6001-7000, cz. 1-2 oprac. A. Jałbrzykowska, J. Zathey, Indeks oprac. A. Jałbrzykowska, Z. Łagodowa, J. Tyszkowska, Kraków 1962-1963, Nr 7001-8000, cz. 1-3 oprac. A. Jałbrzykowska, Indeks oprac. A. Jałbrzykowska, J. Tyszkowska, Kraków 1966-1968 Nr 8001-9000, cz. 1-2 oprac. W. Bandura, A. Jałbrzykowska, Indeks, oprac. W. Bandura, J. Grzybowska, A. Kotula, Kraków 1971-1974; Nr 9001-10000, cz. 1-3, Indeks oprac. J. Grzybowska, E. Malicka, Kraków 1977-1987; Nr 10000-11000, cz. 1: nr 10001-10500, oprac. Z. Koziński, E. Malicka, Z. Pietrzyk, Kraków 1997; Nr 10000-11000, cz. 2: nr 10501-11000, oprac. J. Grzybowska, Z. Koziński, E. Malicka, Z. Pietrzyk, Kraków 2002; Nr 11001-11434, Archiwum domowe Pawlikowskich cz. 1 oprac. I. Bator, J. Grzybowska, M. Jaglarz, U. Klatka, pod red. E. Malickiej Kraków 2008.

„Rozprawy i Sprawozdania z Posiedzeń Wydziału Historyczno-Filozoficznego. Akademji Umiejętności”, 1877, t. 7, [Kraków] 1877, dodatek, s. I-XXX.

${ }^{8}$ Wskazówki do inwentaryzacji rękopisów ułożył z polecenia Komisyi Literackiej Akademii Umiejętności Adam Chmiel, Kraków 1903. Instrukcja poruszała zasadnicze kwestie dotyczące inwentaryzacji rękopisów w bibliotece lub archiwum. 
Akademię Umiejętności Kraków (1935) oraz opracowanie, które służy nadal jako instrukcja katalogowania Wytyczne opracowania rękopisów $w$ bibliotekach polskich (Wrocław 1955). W artykule dokonano porównania katalogów drukowanych rękopisów polskich bibliotek naukowych wydawanych na podstawie wytycznych z 1935 roku oraz współcześnie wydawanymi katalogami, uwzględniającymi aktualne przepisy9.

\section{Pierwsze katalogi drukowane rękopisów polskich bibliotek naukowych}

Pierwszy polski katalog drukowany rękopisów, który wyznaczył ścieżkę tworzenia kolejnych katalogów, to dzieło W. Wisłockiego Katalog Rękopisów Bibljoteki Uniwersytetu Jagiellońskiego, wydany w 1881 roku w Krakowie. Tworzenie katalogu zainicjował w 1874 roku Karol Estreicher ${ }^{10}$. Pierwsza część katalogu zawierała obszerny wstęp i omówienie rękopisów Biblioteki Uniwersytetu Jagiellońskiego, według ówczesnych sygnatur $1-1875^{11}$. W 1877 roku katalog był już przygotowany i gotowy do druku. W obszernym wstępie dr. Wisłockiego odnajdujemy istotne informacje o ponad 500-letniej tradycji Biblioteki Jagiellońskiej oraz listę darczyńców ${ }^{12}$ zbiorów rękopiśmiennych tejże biblioteki. Biblioteka Jagiellońska liczyła wówczas 4176 jednostek w 5226 tomach i zeszytach ${ }^{13}$. Najstarszym obiektem rękopiśmiennym, jaki posiadała Biblioteka Jagiellońska w okresie powstawania katalogu Wisłockiego, był pergamin prof. i dr. medycyny Andrzeja Grzymały - Timaeum Platonis, cum Commento Chalcidii, pisany prawdopodobnie w X wieku lub na początku XI wieku ${ }^{14}$. Katalog opatrzony został na końcu indeksami: osobowym, miejscowości oraz przedmiotowym. Opis katalogowy rozpoczynał się od sygnatury jednostki rękopiśmiennej w bibliotece, cech formalnych (rodzaj materiału na jakim został spisany rękopis, czas powstania, ilość kart) oraz zawierał szczegółowy opisu zawartości.

Katalogi drukowane rękopisów Biblioteki Jagiellońskiej kontynuowano w formie inwentarzy w latach 1962 i 1963 . Dopiero po stu latach od podjęcia przez Wisłockiego, prac nad Katalogiem rękopisów Biblioteki Uniwersy-

\footnotetext{
${ }^{9}$ B. Horodyski, H. Więckowska, Wytyczne opracowania zbiorów rękopiśmiennych w polskich bibliotekach, Warszawa, Wrocław, Kraków 1955.

${ }_{10}$ W. Wisłocki, Katalog rękopisów Biblijoteki Uniwersytetu Jagiellońskiego, cz. 1. Kraków 1881, s. XXXIV.

11 Tamże, s. I-XXXI.

12 Pierwsze dary Biblioteka Uniwersytetu Jagiellońskiego otrzymała już na początku XV w., głównie dzięki zapisom testamentowym profesorów, bakałarzy, uczniów uniwersyteckich.

13 Tamże, s. I.

14 Tamże, s. II.
} 
tetu Jagiellońskiego, przystąpiono do opracowania na nowo katalogu. Przez stulecie nastąpił olbrzymi postęp w nauce światowej i polskiej. W 1955 roku powstała instrukcja opracowywania zbiorów rękopiśmiennych autorstwa B. Horodyskiego i H. Więckowskiej. Potrzebę wydania katalogu wzmagało stałe powiększanie się zbiorów Biblioteki Jagiellońskiej. W dniu 31 XII 1974 roku Biblioteka była w posiadaniu 15284 rękopisów, a więc przeszło czterokrotnie więcej niż przed stu laty. Format opisu katalogowego Biblioteki Jagiellońskiej z 1980 r. powstał na wzorze opracowania Katalogu rękopisów średniowiecznych Biblioteki Kórnickiej. Opis poszczególnych rękopisów następował według przyjętych od czasu Wisłockiego sygnatur, przy opuszczeniu sygnatur przekazanych Archiwum UJ. W opisie każdego rękopisu wyróżniają się trzy części: krótki opis ogólny - zewnętrzny, wykaz zawartości rękopisów oraz opis bibliologiczny. Część trzecia zawiera cechy charakterystyczne dla rękopisu: składki, znaki wodne (względnie rodzaj pergaminu), pismo i zdobienia, noty i glosy, oprawę, proweniencję, notę bibliograficzną. Do opisu katalogu rękopisów średniowiecznych Biblioteki Jagiellońskiej, przyjęto język łaciński za podstawowy język wydania, trudu przełożenia na język polski podjęła się Jadwiga Pacynowa. Katalog został opatrzony indeksami: incipitów, imion i nazw, chronologiczny spis rękopisów, a także zestawienie starych sygnatur z nowymi (konkordancja) ${ }^{15}$. Kolejne tomy zaopatrzone zostały wykazem cytowanych rękopisów ${ }^{16}$.

Jedynym z pierwszych katalogów drukowanych rękopisów powstających równocześnie z katalogiem W. Wisłockiego, jest katalog rękopisów Biblio-

${ }^{15}$ Catalogus codicum manuscriptorum medii aevi Latinorum, qui in Bibliotheca Jagellonica Cracoviae asservantu, Wratislaviae [1982], s. XXIX-XXXIII.

${ }^{16}$ Catalogus codicum manuscriptorum medii aevi Latinorum, qui in Bibliotheca Jagellonica Cracoviae asservantur, Vol. 1-8 (cod. 8-1270). Vol. 2 numeros continens inde ab 332 usque ad 444 composuerunt M. Kowalczyk, M. Markowski, G. Zathey, M. Zwiercan Wratislaviae 1982; Vol. 3 numeros continens inde ab 445 usgue ad 563 composuerunt M. Kowalczyk, A. Kozłowska, M. Markowski, S. Włodek, G. Zathey, M. Zwiercan, Wratislaviae 1984; Vol. 4 numeros continens inde ab 564 usque ad 667 composuerunt M. Kowalczyk, A. Kozłowska, M. Markowski, S. Włodek, G. Zathey, M. Zwiercan, Wratislaviae - 1988; Vol. 5 numeros continens inde ab 668 usque ad 771 composuerunt M. Kowalczyk, A. Kozłowska, M. Markowski, S. Włodek, M. Zwiercan Wratislaviae - 1992. Indices vol. 1 - Wratislaviae 1997; Vol. 6 numeros continens inde ab 772 usque ad 1190 composuerunt M. Kowalczyk, A. Kozłowska, M. Markowski, L. Nowak, A. Sobańska, R. Tatarzyński, S. Włodek, M. Zwiercan Wratislaviae 1996; Vol. 7 numeros continens inde ab 1191 usque ad 1270 composuerunt M. Kowalczyk, A. Kozłowska, M. Markowski, L. Nowak, A. Sobańska, R. Tatarzyński, S. Włodek, W. Zega, M. Zwiercan, Wratislaviae 2000; Vol. 8 numeros continens inde ab 1271 usque ad 1353 composuerunt M. Kowalczyk, A. Kozłowska, M. Markowski, L. Nowak, A. Sobańska, R. Tatarzyński, S. Włodek, W. Zega, M. Zwiercan, 2004 Vol. 9 numeros continens inde ab 1354 usque ad 1430 composuerunt M. Kowalczyk, A. Kozłowska, M. Markowski, L. Nowak, A. Sobańska, R. Tatarzyński, S. Włodek, W. Zega, M. Zwiercan, Wratislaviae 2008. 
teki Czartoryskich w Krakowie - Catalogus codicum scriptorum Musei Principum Czartoryski Cracoviensis ${ }^{17}$. Sygnatury 1-917, Kraków 1877-1893. Na konieczność opracowania katalogu naukowego po raz pierwszy zwrócił uwage dyrektor - Marian Sokołowski. W sprawie opracowania katalogu poproszono W. Wisłockiego, jednak odmówił on wykonania tego zestawienia prawdopodobnie z powodu pracy nad własnym katalogiem. Ostatecznie pracy podjął się J. Korzeniowski, a po jego przeniesieniu się do Lwowa pracę kontynuował S. Kutrzeba, wydając w latach 1908-1913 drugi tom (sygn. 918-1681) ${ }^{18}$. Po objęciu stanowiska dyrektora przez Stanisław Smolkę do dalszego opracowania zaangażowano Oskara Haleckiego. Efektem pracy jest zachowany w rękopisie dwutomowy katalog obejmujący sygn. 1725-2580. Niestety katalog miał duże luki w sygnaturach i różne metody opracowania, dlatego nie został opublikowany ${ }^{19}$. W 1923 roku przerwane prace kontynuował M. Heitzman, który po skatalogowaniu kilku jednostek, opracował projekt nowej instrukcji katalogowania, który przedstawił na posiedzeniu specjalnej komisji powołanej przez PAU. Przedstawiony projekt według dyrekcji zakładał opracowywanie katalogu przez sześćdziesiąt lat, dlatego podjęto się opracowania mniej czasochłonnej publikacji - inwentarza. Przygotowanie tego wydawnictwa zlecono K. Buczkowi. Niestety inwentarz nie doczekał się publikacji. Wydanie wstrzymano do czasów uporządkowania Archiwum Gospodarczego. W 1930 roku zapoznał się z pracami nad katalogiem nowy dyrektor M. Kukiel, który stwierdził, że opracowany materiał nie nadaje się do wydania drukiem.

\section{Dynamiczne powstawanie katalogów drukowanych rękopisów bibliotek naukowych - kontynuowanie opracowań wcześniejszych katalogów}

Podejmując temat katalogów Biblioteki Uniwersytetu Jagiellońskiego nie sposób w tym miejscu pominąć opracowań Katalogów rękopisów Biblioteki Naukowej PAU i PAN w Krakowie. Pierwszym badaczem, który zainicjował tworzenie katalogu rękopisów w 1869 roku był dr W. Seredyński: Rękopismy Towarzystwa Naukowego Krakowskiego systematycznie zestawione ${ }^{20}$. Katalog ten obejmował zaledwie 445 rękopisów, a w czasie powstawania katalogu

\footnotetext{
${ }^{17}$ Katalog rękopisów Biblioteki Czartoryskich w Krakowie. Sygnatury 1682-2000, oprac. M. Kukiel, Kraków 1988, s. VI.

18 Tamże, s. VI

19 Tamże, s. VII.

${ }^{20}$ Katalog rękopisów Akademii Umiejętności w Krakowie zestawione przez W. Seredyńskiego, Kraków 1869, s. I.
} 
Jana Czubka w 1906 roku zasoby rękopiśmienne liczyły już 1588 jednostek $^{21}$. Z powodu krótkiego czasu i potrzeby szybkiego stworzenia katalogu opisy rękopisów zawierały najważniejsze informacje. Każdy rękopis traktowano indywidualnie, różnica opracowania zależała od czasu powstania manuskryptu. Rękopisy do XVI wieku posiadały większą szczegółowość w opisie. Akta prywatne i polityczne, korespondencje, mowy zawierały jedynie ogólnikowe treści ${ }^{22}$. Czubek, przystępując do opracowywania dokumentów, posłużył się w swoim dziele Katalogiem Archiwum Akt Dawnych miasta Krakowa, wydanym przez Stanisława Krzyżanowskiego ${ }^{23}$. W 1912 roku J. Czubek wydał uzupełnienie Katalogu Rękopisów Akademii Umiejętności w Krakowie. Dodatek I. Rękopisy nr. 1589-1810. Niestety J. Czubek nie uchronił się od pomyłek i niedociągnięć merytorycznych. Regestry często nie oddają dokładnie treści dokumentów, a niejednokrotnie fałszywie informują czytelnika. Sporadycznie wykazywał wydawnictwa źródłowe opracowanych przez niego dokumentów ${ }^{24}$.

Idea opracowania katalogów rękopisów Akademii Umiejętności w Krakowie narodziła się ponownie w latach sześćdziesiatych i siedemdziesiątych XX wieku ${ }^{25}$. W 1966 i 1968 roku ukazały się dwa tomy Katalogu dokumentów pergaminowych Biblioteki Polskiej Akademii Nauk w Krakowie. Cz. I. Dokumenty z lat 1113-1571 oraz Cz. II. Dokumenty z lat 1573-1787, opracowane przez K. Dziwika. Pomoc przy opracowaniu katalogu stanowiła dla autora instrukcja Opracowania dokumentów pergaminowych i papierowych $w$ archiwum $^{26}$. Wskazówki te ograniczały się jedynie do inwentaryzacji rękopisów, dlatego Dziwik wzorował się na schemacie opisu dokumentów, na katalogach rękopisów drukowanych w Polsce po II wojnie światowej. Korzystał zwłaszcza z katalogów opracowanych przez A. Fastnachta i C. Kacz-

${ }^{21}$ Katalog rękopisów Akademii Umiejętności w Krakowie zestawił Jan Czubek, Kraków 1906, s. I.

22 Tamże, s. II.

${ }^{23}$ K. Dziwik, Katalog dokumentów pergaminowych Biblioteki Polskiej Akademii Nauk w Krakowie. Cz. 1. Dokumenty z lat 1113-1571, Wrocław [i. in.] 1866, s. V.

${ }^{24}$ Tamże, s. VI.

${ }^{25}$ Katalog Rękopisów Biblioteki PAN w Krakowie. Sygnatury 1811-2148, oprac. Z. Jabłoński, A. Preissner, Kraków 1962; Sygnatury 2149-2298, oprac. Z. Jabłoński, A. Preissner, B. Schnaydrowa, 1965; Sygnatury 2299-2630, oprac. Z. Jabłoński, A. Preissner, B. Schnaydrowa, Kraków 1967; Sygnatury 2631-2906, oprac. Z. Jabłoński, A. Preissner, B. Schnaydrowa, Kraków 1969; Sygnatury 2907-3606, oprac. Z. Dużyk, B. Schnaydrowa, pod red. Z. Jabłońskiego, Kraków 1973;. Sygnatury 3607-4003, oprac. B. Schnaydrowa, J. Staszel, pod red. Z. Jabłońskiego, Kraków 1976; Sygnatury 4004-4567, oprac. B. Schnaydrowa, J. Staszel, pod red. Z. Jabłońskiego, Kraków 1979.

${ }^{26}$ K. Kaczmarczyk, J. Karwasińska, A. Wolff, Opracowanie dokumentów pergaminowych i papierowych w archiwum [w:] „Archeion”, t. 19-20, Warszawa 1951, s. 139-177. 
marczyka ${ }^{27}$. Ostatecznie uczony wykorzystał sposób opisywania Fastnachta, tzn. treść dokumentów i elementów opisu zostały napisane w języku polskim. Kolejność opisu katalogowego przedstawia się następująco: data (rok, dzień, miesiąc), miejsce wystawienia i numer bieżący dokumentu, streszczenie zawartości, język w jakim został zapisany, wymiary, noty dotyczące treści, proweniencji, oblat, intabulacji. Warto zaznaczyć, że w obydwu tomach sporządzonych przez K. Dziwika występują zbiory rękopiśmienne, jak i druki.

Kolejny owocny etap tworzenia katalogów rękopisów Biblioteki Polskiej Akademii Nauk w Krakowie przypada na lata dziewięćdziesiąte. W 1991 roku ukazał się drukiem Katalog Rękopisów Biblioteki Polskiej Akademii Nauk w Krakowie. Sygnatury 6001-6194 opracowane zostały przez zespół J. Dużyk, B. Schnayderowa, J. Staszel ${ }^{28}$. Inwentarz ten był kontynuacją katalogu wydanego w 1986 roku. Celowo pominięto sygnatury 4677-5587, zawierające spuściznę naukową ks. Jana Fijałka, pozostawioną do późniejszego opracowania ${ }^{29}$. Podobnie jak w poprzednich tomach zastosowano inwentarzowy typ katalogu zbiorów rękopiśmiennych w układzie sygnaturowym, odzwierciedlający kolejność wpływów i katalogowania zbiorów ${ }^{30}$. Po opisie formalnym następuje opis wewnętrzny, treściowy. Po wykazie treści rękopisu następują szczegóły bibliologiczne, ograniczające się głównie do opisania zabytkowych opraw, podania ważniejszych notatek bibliograficznych, omówienie stanu zachowania jednostki rękopiśmiennej i określenia proweniencji. Katalog posiada indeks haseł osobowych, geograficznych i rzeczowych ${ }^{31}$. Kolejne katalogi Biblioteki Polskiej Akademii Nauk zawierały opracowanie spuścizny ks. Jana Fijałka ${ }^{32}$. Opis katalogowy nawiązywał do zasad stosowanych we wcześniejszych tomach.

27 A. Fastnacht, Katalog dokumentów Biblioteki Zakładu Narodowego im. Ossolińskich, cz. 1. Dokumenty z lat 1507-1700, Wrocław 1953; C. Kaczmarczyk, Catalogus diplomatum pergameneorunm Universitatis Jagellonicae Cracoviensis, Cracoviae 1953.

${ }^{28}$ Katalog rękopisów Biblioteki Polskiej Akademii Nauk w Krakowie, oprac. J. Dużyk, B. Schnayderowa, J. Staszel, Wrocław [i. in.] 1991.

29 Tamże, s. 5.

30 Tamże, s. 8.

31 Tamże, s.10.

${ }^{32}$ Katalog Rękopisów Biblioteki PAN w Krakowie. Sygnatury 4677-4715, oprac. J. Staszel, Kraków 1995; Sygnatury 4716-4796, oprac. B. Sieraczyńska, Z. Solak, J. Staszel, K. Szymurowa, Kraków1998; Sygnatury 4797-4886, oprac. J. Dużyk, Kraków 1996. 


\section{Katalogi rękopisów Biblioteki Kórnickiej Polskiej Akademii Nauk}

Znaczącą kolekcję rękopisów odnajdziemy w Bibliotece Kórnickiej Polskiej Akademii Nauk, których zbiór stanowi 14000 jednostek, w tym 100 manuskryptów średniowiecznych ${ }^{33}$. Publikowanie wykazów rękopisów zaczęto w latach trzydziestych XX wieku, opracowując inwentarze wybranych kolekcji ${ }^{34}$. Prace nad katalogami drukowanymi rękopisów Biblioteki Kórnickiej Polskiej Akademii Nauk, zapoczątkował uznany badacz Jerzy Zathey ${ }^{35}$. Istotnym katalogiem dokumentującym zbiory rękopiśmienne Biblioteki Kórnickiej jest Katalog rękopisów staropolskich Biblioteki Kórnickiej XVI-XVIII wieku ${ }^{36}$. Opublikowany w 1971 roku pierwszy tom Katalogu, był próbą wypracowania nowoczesnego modelu katalogu rękopisów, odpowiadający specyfice badań nad rękopisami staropolskimi. Podstawę metodyczną stanowiły wytyczne z 1955 roku, katalog obejmuje zwarty materiał w układzie rzeczowym i chronologicznym ${ }^{37}$. Niniejsze katalogi zawierają indeksy: osób i nazw geograficznych, indeks incipitów.

\section{Katalogi rękopisów Biblioteki Zakładu im. Ossolińskich we Wrocławiu}

Cykl publikacji informujących o zbiorach rękopiśmiennych Biblioteki Zakładu im. Ossolińskich we Wrocławiu, zapoczątkował Wojciech Kętrzyński w 1881 roku. Był to - Katalog rękopisów Biblioteki Narodowej im. Ossolińskich, t. 1. We wstępie do katalogu odnajdujemy informację o stanie liczebnym ówczesnych rękopisów biblioteki, które stanowiły 2901 rękopisów,

${ }^{33}$ Zbiory rękopisów $w$ bibliotekach i muzeach $w$ Polsce, oprac. D. Kamolowa, T. Sieniatycka, Warszawa 2003, s. 85.

34 Inwentarz rękopisów Biblioteki Kórnickiej. z. 1. Sygn. 1-1612, oprac. S. Bodniak, Kórnik 1930, k. VIII, s. 133 (mps powiel.); z. 2. Sygn. 1613-2700, oprac. J. Łyczakowa, M. Olszewska, Poznań 1963, s. V, 1 nlb., 202 [oraz:] Indeks osób, miejscowości i rzeczy do drugiego zeszytu Inwentarza, oprac. J. Wiesiołowski, Poznań 1965, s. 72. z. 4. Sygn. 11008-12000, oprac.: R. Marciniak, J. Wiesiołowski. Cz. 1, Kórnik 1983, s. 395; Cz. 2. Indeksy, oprac. R. Marciniak, Kórnik 1983, s. 247. z. 5. Sygn. 12001-13000, oprac. S. K. Potocki, Kórnik 1993, s. 439; Z. 6. Sygn. 13001-13499. Pamiętniki robotników, oprac. J. Niemir, Kórnik 2001, s. 104.

${ }^{35}$ Katalog rękopisów średniowiecznych Biblioteki Kórnickiej, oprac. J. Zathey, Wrocław [i in.] 1963, s. LI, 1 nlb., 734, 2 nlb., tabl. 14.

${ }^{36}$ Katalogi rękopisów staropolskich Biblioteki Kórnickiej XVI-XVIII w. t. 1., oprac. R. Marciniak, M. Muszyński, J. Wiesiołowski. Wrocław [i in.] 1971, s. XI, 604 (Zbiory historyczne, głównie nabytki XIX w.); t. 2., oprac. R. Marciniak, M. Muszyński, J. Wiesiołowski. Wrocław [i in.] 1985, s. X, 607, err. (Głównie zbiory dotyczące panowania Zygmunta Starego i Zygmunta Augusta); [brak tomu 3 i 4]; t. 5, oprac. A. Mężyński, K. Nizio, Kórnik 1992, s. VII, 1 nlb., 503.

37 Tamże, s. VIII. 
odnoszących się przeważnie do historii i literatury polskiej. Pierwszy tom katalogu zawierał zakres sygnatur od 1-226, uczony postulował, aby każdy z tomów nie zawierał zbyt dużo opisów, tym samym przewidywał kata$\log \mathrm{w}$ formie 5 tomów. Ostatecznie badacz przygotował i wydał trzy tomy katalogów rękopisów z zakresem sygnatur: t. 1. - sygn. 1-226, t. 2 - sygn. 227-561 oraz t. 3 - sygn. 562-1504 ${ }^{38}$. Katalogi te zawierały indeksy nazwisk, osobowy oraz miejscowości.

Katalog powstał, „[...] aby ułatwić korzystanie z zasobów rękopiśmiennych nie tylko publiczności miejscowej, lecz i uczonym zamiejscowym [...]"39. Tworząc opisy katalogowe, Kętrzyński trzymał się pisowni pierwotnej, modyfikował jedynie pisownię z XV wieku i czasów dawniejszych. Opis katalogowy rękopisów zawierał: rodzaj materiału, na jakim został spisany, czas powstania, liczbę kart, krótką informację o oprawie oraz szczegółowy spis zawartości rękopisu.

Pracę Kętrzyńskiego kontynuowano w 1948 roku. Powstał wówczas Inwentarz rękopisów Biblioteki Narodowej im. Ossolińskich we Wrocławiu ${ }^{40}$, opracowany zbiorowo pod redakcją dr Jadwigi Turskiej, t. 1-2, 1948-1949 rok. Kolejno opublikowany tom trzeci, przygotowany i wydany drukiem w 1966 roku nawiązywał „[...] do tradycji dokładnych opisów katalogowych Kętrzyńskiego [... " ${ }^{\prime 11}, \mathrm{z}$ uwzględnieniem nowych zasad opracowania. Z łatwością można było zauważyć różnice w sposobie opracowania poszczególnych partii rękopisów. Wynikały one z tego, iż opisy powstawały przed i po wprowadzeniu ogólnopolskich wytycznych opracowania rękopisów ${ }^{42}$. W tomie trzecim ujednolicono zasady opracowania, dodając wyczerpujące informacje

${ }^{38}$ W. Kętrzyński, Katalog rękopisów Biblioteki Zakładu Narodowego im. Ossolińskich, t. 1 (1-226), Lwów 1881; Katalog rękopisów Biblioteki Zakładu im. Ossolińskich, t. 2 (227-561), Lwów 1886; Katalog rękopisów Biblioteki Zakładu Narodowego im. Ossolińskich, t. 3 (562-1504), Lwów 1898.

39 W. Kętrzyński, Katalog rękopisów Biblioteki Narodowej im. Ossolińskich, t. 1, Lwów 1881, s. V.

${ }^{40}$ Inwentarze dokumentujące zbiory rękopiśmienne Biblioteki Narodowej im. Ossolińskich: Inwentarz rękopisów Biblioteki Zakładu Nar. Im. Ossolińskich we Lwowie (nr 1505 do 5500), mps powiel., Lwów 1926; Inwentarz rękopisów Biblioteki Zakładu Narodowego im. Ossolińskich we Lwowie (nr 5501 do 6000), mps powiel., Lwów 1934; M. Gębarowicz, Katalog rękopisów Biblioteki Gwalberta Pawlikowskiego, Lwów 1929 oraz reedycja Wrocław 1949; S. Inglot, Inwentarz archiwum XX Lubomirskich (linia dąbrowieńska), Warszawa 1937, oprac. pod red. J. Turskiej, Wrocław 1949; Indeks do inwentarza rękopisów [...] (t. 1-2), Wrocław 1962; t. 3: Rękopisy 11981-13000, oprac. A. Dician i J. Loret-Heintsch, pod red. A. Fastnachta, Wrocław 1966; t. 4: Rękopisy 1300113725, oprac. A. Dician, L. Górecki, A. Kapłon i in., pod red. A. Fastnachta, Wrocław 1972.

${ }^{41}$ Inwentarz rękopisów Biblioteki Zakładu Narodowego im. Ossolińskich we Wrocławiu, Rękopisy 11981-13000, pod red. A. Fastanachta, Wrocław [i. in.] 1966, t. III, s. VI.

${ }^{42}$ Tamże, s. VI. 
o zawartości rękopisów. Opisy katalogowe zostały sporządzone według Wytycznych opracowania rękopisów w bibliotekach polskich ${ }^{43}$. Katalog rękopisów zawiera nieliczne odstępstwa od zawartych zasad, które podyktowane zostały względami praktycznymi. Zmieniono głównie formaty rękopisów Biblioteki, podzielono je tylko na cztery formaty. Zamiast foliacji zastosowano paginację ze względu na mikrofilmowanie i funkcję praktyczną. Odstępstwem od wytycznych jest także zaopatrywanie kolejnymi numerami inwentarza poszczególnych tomów zbiorów korespondencji, a nie jedną sygnaturą całego zbioru $^{44}$. Każdą pozycję opisu katalogowego rozpoczyna numer inwentarza, format, sygnatura. Następnie podane są elementy opisu zewnętrznego: język, czas powstania, wymiary, ilość tomów itp. ${ }^{45}$ Całość inwentarza zaopatrzona została $\mathrm{w}$ indeks obejmujący hasła osobowe, rzeczowe i proweniencji ${ }^{46}$.

W kolejnych wydaniach tomów Katalogu rękopisów Biblioteki Zakładu Narodowego im. Ossolińskich ${ }^{47}$ kontynuowano tworzenie opisów z wytycznymi B. Horodyskiego i H. Więckowskiej.

\section{Katalogi rękopisów Biblioteki Uniwersytetu Wrocławskiego}

Znacząca kolekcja rękopisów (14 000 jednostek rękopisów, ponad 17000 autografów) znajduje się w Bibliotece Uniwersytetu Wrocławskiego. Po-

${ }^{43}$ B. Horodyski, H. Więckowska, Wytyczne opracowania rękopisów w bibliotekach polskich, Wrocław 1955.

${ }^{44}$ Inwentarz rękopisów Biblioteki Zakładu Narodowego im. Ossolińskich we Wrocławiu, Rękopisy 11981-13000, s. VIII.

${ }_{45}$ Tamże, s. IX.

${ }^{46}$ Tamże, s. X.

${ }^{47}$ Inwentarz rękopisów Biblioteki Zakładu Narodowego im. Ossolińskich we Wrocławiu, pod. red. A. Fastnachta, Wrocław [i. in.] 1972, t. IV, s. VI; A. Fastnacht, Inwentarz rękopisów Biblioteki Zakładu Narodowego im. Ossolińskich we Wrocławiu, Wrocław [i. in] 1975, t. V, s. VI-VII; t. 7: Rękopisy 14601-15060, oprac. Ł. Częścik i in., pod red. K. Korzona, Wrocław 1983; t. 8: Rękopisy 15061-15320, oprac. A. Łongiewska, F. Sawicka, pod red. K. Korzona, Wrocław 1984; t. 9: Rękopisy 15321-15680, oprac. Ł. Częścik i in., pod red. K. Korzona, Wrocław 1984; t. 10: Rękopisy 15681-15960 oprac. E. Galos, L. Górecki, K. Korzon i in., pod red. K. Korzona, Wrocław 1986; t. 11: Rękopisy 15961-16220, oprac. E. Galos i in., pod red. K. Korzona, Wrocław 1989; t. 12: Rękopisy 16221-16500, oprac. E. Galos i in., pod red. D. Platt, Wrocław 1992; t. 13: Rękopisy 16501-16800, oprac. Ł. Częścik i in., pod red. W. Sonnak, Wrocław 1993; t. 14: Rękopisy 1680117050, oprac. K. Korzon pod red. W. Sonnak, Wrocław 1995; t. 15: Rękopisy 17051-17260, oprac. M. Matwijów, E. Ostromęcka, W. Sonnak, pod red. W. Sonnak, Wrocław 1997; t. 16: Rękopisy 17261-17708, oprac. K. Korzon, M. Matwijów, E. Ostromęcka, pod red. W. Sonnak, Wrocław 1998; t. 17: Rękopisy 17709-17945, oprac. H. Kulesza i in., pod red. W. Sonnak, Wrocław 2000; t. 18: Rękopisy 17946-18299, oprac. H. Kulesza i E. Ostromęcka, pod red. W. Sonnak, Wrocław 2003; t. 19: Rękopisy 18300-18630, oprac. A. Knychalska i M. Matwijów, pod red. W. Sonnak, Wrocław 2008 s. 199-201. 
czątkowo katalogowanie rozpoczęto od dwutomowego rękopiśmiennego katalogu Johanna Christopha Friedricha (1775-1836), pierwszego kustosza zbioru rękopisów - Catalogus codicum scriptorum, qui in Bibliotheca Regia ac Academica Wratislaviensi servantur, sygn. akc.1967/1). Opracowany w latach 1821-1823, zaopatrzony w indeksy i uzupełniany następnie przez kolejnych bibliotekarzy. Pierwszy katalog drukowany rękopisów Biblioteki Uniwersytetu Wrocławskiego, został opracowany i opublikowany w języku niemieckim przez W. Göbera i J. Klaperra ${ }^{48}$. Dalsze prace nad stworzeniem pełnego katalogu rękopisów kontynuował K. Kl. Jażdżewski. W 1982 roku opublikował Catalogus Manu Scriptorum Codium Medii Aevi Latinorum Signa 180-260 Comprehendens ${ }^{49}$. Jażdżewski wykorzystał do opisu katalogowego Wytyczne opracowania rękopisów w bibliotekach polskich z 1955 roku $^{50}$. Informacje o rękopisie dzielą się na trzy części: podstawowe dane bibliologiczne (sygnatura, język tekstu, czas ich powielania, materiał pisarski, wymiar bloku kodeksu, liczbę kart, określenie oprawy), nota o iluminacji oraz zawartość rękopisu i opis bibliologiczny. Na opis bibliologiczny składają się: znaki wodne, ilość rąk, sposób rubrykowania, elementy oprawy, stan zachowania, proweniencja rękopisu, sygnatura ${ }^{51}$.

\section{Katalogi drukowane rękopisów Biblioteki Narodowej w Warszawie}

Omówienie zamyka centralna biblioteka kraju - Biblioteka Narodowa w Warszawie. Celowo na zakończenie wybrano prezentację tejże instytucji, aby szczegółowo zilustrować problem stworzenia centralnego katalogu zbiorów rękopiśmiennych w Polsce. Scharakteryzowanie zbiorów rękopiśmiennych Biblioteki Narodowej pod względem ich zawartości jest niełatwe ze względu na ich ogromne zróżnicowanie oraz powrót w latach 1923-1934 tzw. rewindykatów, które w okresie rozbiorów Polski zostały skonfiskowane przez rząd carski i wywiezione do Petersburga, a na podstawie traktatu ryskiego (1921) zostały zwrócone Polsce przez Związek Radziecki. Podstawę stworzenia kolekcji zbiorów rękopiśmiennych zapoczątkował wpływ rękopisów z Biblioteki Muzeum Narodowego Polskiego w Rapperswilu

${ }^{48}$ Die Handschriften der Staats- und Universitätsbibliothek Breslau. Bd. 1. Lief. 1-2. Bearb. Von W. Göber, J. Klapper, Leipzig 1938-1939.

${ }_{49}$ D. Kamolowa, T. Sieniatycka, Zbiory rękopisów w bibliotekach i muzeach w Polsce, Warszawa 2003 , s. 514.

${ }^{50}$ C. Cl. Jażdżewski, Catalogus Manu Scriptorum Codicum Medii Aevi Latinorum Signa 180260 Comprehendens. Wratislaviae [i in.] 1982, s. 16.

${ }^{51}$ Tamże, s. 16-18. 
w 1927 roku. Pierwszy katalog wydany przez Bibliotekę Narodową w 1929 roku, dokumentował zbiory rękopiśmienne biblioteki rapperswilskiej. Pierwszy tom opracował Adam Lewak, drugi tom przygotowany został przy współpracy z Heleną Więckowską ${ }^{52}$. Badacze ci zasłużyli się dla polskiej nauki, opracowując instrukcje katalogowania zbiorów rękopiśmiennych. Tom pierwszy katalogu obejmuje rękopisy od dziejów emigracji do wybuchu powstania styczniowego, tom drugi zawiera materiały polskiej emigracji między 1870 a $1927^{53}$. Przy katalogowaniu starano się zgrupować obok siebie rękopisy, które łączy ten sam sposób nabycia oraz okres dziejów polskich ${ }^{54}$. W pracy tej kierowano się Wskazówkami do katalogowania rękopisów, które opracowała Komisja Historyczna Polskiej Akademii Umiejętności w Krakowie w 1935 roku. W obydwu tomach prezentacje opisu katalogowego rozpoczyna sygnatura oraz cechy formalne rękopisu. W zawartości odnajdujemy szczegółowy omówienie jednostek składających się na zespół. Rękopisy pogrupowane są tematycznie np. (Stowarzyszenia Emigracyjne, korespondencja Z. Miłkowskiego) oraz chronologicznie np. (powstanie 1863-1864 roku, zabór pruski). Katalog Zbiorów Biblioteki Rapperswilskiej zaopatrzony jest $\mathrm{w}$ odrębny indeks $\mathrm{w}$ układzie alfabetycznym, obejmujący sygnatury $1-2299^{55}$. Tomy te mają obecnie znaczenie jedynie historyczne, gdyż opisane w nich zbiory uległy zniszczeniu w czasie drugiej wojny światowej. Zachowane rękopisy rapperswilskie po startach wojennych dokumentują również katalogi: t. 4 zawierający wykaz zachowanych rękopisów z Biblioteki Rapperswilskiej, opracowanych pod nowymi sygnaturami oraz fragmenty zbioru w tomach 5, 9, 10, 12 oraz 13 . Kolejny t. 3. Rękopisy 2300-2666. Zbiory Batignolskie i Towarzystwa Przyjaciót Polski w Londynie opracowany przez Helenę Więckowską ma również charakter historyczny. Kolejne tomy od IV do XIV zawierają rękopisy pogrupowane tematycznie i chronologicznie ${ }^{56}$.

52 A. Lewak, H. Więckowska, Zbiory Biblioteki Rapperswilskiej. Rękopisy Nr 1315-2299, t. II, Warszawa 1938. Oby dwa tomy zostały zaopatrzone w osobny indeks.

${ }_{53}$ Tamże, s. VII.

${ }^{54}$ Tamże, s. IX.

55 T. 2. cz. 2. Indeksy do katalogu rękopisów. Sygn. 1-2299, Warszawa 1938.

56 T. 4. Rękopisy 2667-3000 i 7001-7200. Korespondencja i drobne utwory XIX i XX wieku, pod red. B. Horodyskiego, Wrocław 1955; t. 5. Rękopisy 5001-6000. Spuścizny literackie i naukowe XIX i XX wieku, pod red. B. S. Kupścia, Warszawa 1966; t. 6. Rękopisy 6001-6600. Utwory i spuścizny literackie, pamiętniki i inne materiały źródłowe historyczne od połowy XVIII do połowy XX w., pod red. B. S. Kupścia, Warszawa 1963; t. 7. Rękopisy 6601-7000. Zbiory Morstinów, Radziwiłtów, Potockich i inne rękopisy XVI-XVIII w., pod red. K. Muszyńskiej, Warszawa 1969; t. 8. Rękopisy 7201-7600. Spuścizny literackie i naukowe XIX i XX wieku, pod red. Barbary Kocówny, Warszawa 1970; t. 9. Rękopisy 7601-8000. Spuścizny literackie i naukowe, pamiętniki i inne materiały z XIX i XX wieku, oprac. B. Koc, Warszawa 1979; t. 10. Rękopisy 8301-9000. Archiwa rodzinne Fredrów 
Po długiej przerwie spowodowanej II wojną światową, w 1955 roku powstał kolejny tom katalogu rękopisów stworzony przez Bohdana Horodyskiego, współtwórcę Wytycznych opracowania rękopisów w bibliotekach polskich z 1955 roku. Kierownik Zakładu Rękopisów Biblioteki Narodowej w latach 1945-1956, zapoczątkował tradycję tworzenia katalogów drukowanych rękopisów Biblioteki Narodowej, zgodnie z instrukcją opracowaną wspólnie z Heleną Więckowską. Od tomu piątego zaczęto stosować ujednolicone opisy formalne, poświęcono również uwagę wcześniej opracowanym katalogom, aby dostosować wszystkie opisy do zasad Wytycznych opracowania rękopisów bibliotek polskich ${ }^{57}$. W drobnych wyjątkach stosowano niewielkie odchylenia, np. poszczególne elementy opisu zewnętrznego podane w nagłówku przed tytułem rękopisu, są oddzielane przecinkami zamiast zalecanych w Wytycznych kropek. Opisy zawierały niewielkie zmiany w sposobie zapisu, jednak konsekwentnie trzymano się instrukcji z 1955 roku $^{58}$. Największe trudności w opracowaniu zbiorów rękopiśmiennych Biblioteki Narodowej stanowiły miscellanea, których opisy były dyskusyjne. Zastosowano przy opracowaniu tego typu dokumentów dwie możliwości katalogowania: dokładny opis zawartości rękopisu - karta po karcie oraz kryterium uporządkowania materiału tematycznie ${ }^{59}$. Każdy z kolejnych tomów katalogów drukowanych rękopisów Biblioteki Narodowej zaopatrzony jest w różnorodne skorowidze (indeksy) i wykazy, np.: skorowidz osób i miejscowości, skorowidz rzeczowy, skorowidz proweniencji, skorowidz imion własnych, skorowidz chronologiczny do materiałów historycznych w układzie alfabetycznym oraz wykazy skrótów oraz konkordancje sygnatur. Katalogi drukowane rękopisów Biblioteki Narodowej zawierają doskonały aparat pomocniczo-wyszukiwawczy, ułatwiający w znaczny sposób korzystanie z katalogu oraz odnalezienie właściwego rękopisu.

i Römerów, zbiory dawnej Biblioteki Ordynacji Krasińskich oraz inne rękopisy XIX-XX w., pod red. D. Kamolowej, B. Smoleńskiej, Warszawa 1972; [brak tomu 11]; t. 12. Sygn. 9401-9800. Rękopisy XIX i XX wieku. Pod red. K. Muszyńskiej, Warszawa 1992; t. 13. Sygn. 9801-10200. Rękopisy $z$ końca XVIII-połowy XX wieku, oprac. Z. Krajewska, Warszawa 1997; t. 14. Sygn. 10201-10600. Rękopisy XIX-XX w. Spuścizny literackie i naukowe XIX i XX w., oprac. C. D. Pomianowska, Warszawa 2003.

${ }^{57}$ Katalog rękopisów; t. 5. Rękopisy 5001-6000. Spuścizny literackie i naukowe XIX i XX w., pod red. B. S. Kupuścia, Warszawa 1966, s. 9.

${ }^{58}$ Katalog rękopisów; t. 6. Rękopisy 6001-6600. Utwory i spuścizny literackie, pamiętniki i inne materiały źródłowe historyczne od połowy XVIII do połowy XX wieku, pod red. B. S. Kupuścia; Warszawa 1964, s. VIII-IX.

${ }^{59}$ Katalog rękopisów. t. 7. Rękopisy Morstinów, Radziwiłłów, Potockich i inne rękopisy XVI-XVIII w., pod. red. K. Muszyńskiej,Warszawa 1969 r., s. XXI-XXII. 
Najnowszy katalog drukowany rękopisów, który ma cechy inwentarza, stanowi publikacja opracowana przez Jerzego Kaliszuka oraz Sławomira Szyllera - Inwentarz rękopisów do połowy XVI wieku w zbiorach Biblioteki Narodowej, wydany w 2012 roku. Katalog zawiera wykaz najstarszych rękopisów Biblioteki Narodowej do połowy XVI wieku. Autorzy włączyli do niego dwa najstarsze zabytki rękopiśmienne spisane na papirusie w II i III wieku $^{60}$. Katalog ten miał zawierać rękopisy średniowieczne, jednak za datę umowną przyjęto rok 1520, w którym następuje w Polsce wyparcie książki rękopiśmiennej przez drukowaną ${ }^{61}$. W katalogu uwzględniono również nieopublikowane dotychczas $\mathrm{w}$ żadnym katalogu rękopisy powstałe przed 1550 rokiem. Stan opracowania opisu katalogowego jest różnorodny pod względem stopnia szczegółowości. We wstępie autorzy nie powołują się na żadne instrukcje, jednak sposób prezentacji opisu ma strukturę Wytycznych z 1955 roku. Opis zamieszczony w inwentarzu zawiera: aktualną sygnaturę, podstawowy opis kodeksu - cechy formalne, tytuł kodeksu, zawartość obiektu, stan zachowania, zdobienia, proweniencja, konkordancje, bibliografie oraz informacje o zmikrofilmowaniu rękopisu ${ }^{62}$. Katalog inwentarzowy wyposażony jest w następujący aparat wyszukiwawczy: indeks osobowy, indeks proweniencji, indeks chronologiczny rękopisów oraz konkordancje sygnatur. Twórcy katalogu doskonale uzupełnili dotychczas wydane katalogi rękopisów Biblioteki Narodowej, uwzględniając przy tym różnorodny charakter zbiorów rękopiśmiennych oraz historię tychże materiałów.

\section{Podsumowanie}

Po przeanalizowaniu 91 drukowanych katalogów rękopiśmiennych nadrzędnych polskich bibliotek naukowych, posiadających kolekcje rękopisów powyżej 15 000, uzyskano jednoznaczne informacje o sposobie tworzenia katalogów, zasad opracowania manuskryptów, konstrukcji aparatu pomocniczego oraz charakteru wstępów twórców katalogów. Katalogi drukowane rękopisów bibliotek naukowych rozpoczynają się z reguły wstępami (przedmowami) twórców, streszczając: zakres tematyczny i chronologiczny katalogu, szczegóły powstania biblioteki i gromadzenia zbiorów rękopiśmiennych danej instytucji. Odstępstwa od tej reguły zauważalne są przy kontynuowaniu prac katalogowania, wydawnictwach wielotomowych. Nierzadko wstępy

\footnotetext{
${ }^{60}$ Inwentarz rękopisów do połowy XVI wieku w Zbiorach Biblioteki Narodowej, oprac. J. Kaliszuk. S. Szyller, Warszawa 2012, s. 7.

61 Tamże, s. 8.

${ }^{62}$ Tamże, s.11-12.
} 
katalogów stanowią jedyne źródło wiedzy o historii gromadzenia księgozbioru i bibliotece. Najważniejszą część katalogu stanowią opisy poszczególnych jednostek rękopiśmiennych, na które składają się następujące elementy: sygnatura - opis formalny, opis wewnętrzny rękopisów (treść) oraz aparat pomocniczy wyposażony w skorowidze, indeksy: indeks haseł osobowych, miejscowości (geograficzny) i rzeczy; indeks haseł topograficznych w porządku alfabetycznym. W katalogach, w których grupę tematyczną stanowią rękopisy średniowieczne, występują indeksy incipitów, eksplicitów oraz proweniencji (występowanie proweniencji w rękopisach do 1. połowy $\left.\mathrm{XVIII} \mathrm{w}^{63}\right)$. Sporadycznie w katalogach występują np. indeksy fotografii i podobizn, indeks pocztówek i fotografii, zależne jest to przede wszystkim od zgromadzonych materiałów wewnątrz teczki (jednostki). Opis katalogowy zamyka informacja o zmikrofilmowaniu obiektu. Ważną część w strukturze katalogu pełni wykaz zmian w sygnaturach biblioteki (konkordancja).

Opisy zbiorów rękopiśmiennych w katalogach drukowanych rękopisów bibliotek naukowych wydanych po 1955 roku, sporządzone są według Wytycznych opracowania rękopisów bibliotek polskich - B. Horodyskiego i H. Więckowskiej. Przed opracowaniem jednolitej instrukcji katalogowania zbiorów rękopiśmiennych wzorowano się na poprzednikach, którzy wcześniej opublikowali katalogi. Dla pierwszych uczonych tworzących katalogi, modelowy przykład stanowiły opracowania W. Wisłockiego oraz S. Kutrzeby. Dodatkowo należy pamiętać, iż wielokrotnie podejmowano się przed 1955 rokiem opracowania projektu instrukcji katalogowania, w którym przede wszystkim ogromną rolę spełniło krakowskie środowisko rękopiśmienników.

W 1936 roku K. Buczek na IV Zjeździe Bibliotekarzy w Warszawie, dokonał podsumowania stanu opracowania zbiorów rękopiśmiennych w Polsce. Wykazał wówczas, iż skatalogowanych było zaledwie 1/3 manuskryptów znajdujących się w bibliotekach naukowych. Trudno współcześnie określić, jaka jest skala opracowania materiałów rękopiśmiennych w postaci katalogów drukowanych rękopisów. Jednak stan pracy daleki jest od kompletności, gdyż wiele bibliotek nie posiada skatalogowanych zbiorów rękopiśmiennych. Problem zebrania całościowych informacji o zbiorach rękopisów wynika z burzliwej historii kraju, i tym samym rozproszeniu wielu dokumentów. Jeszcze przed II wojną światową podkreślał ten problem K. Buczek: wręcz niepraw-

${ }^{63}$ Katalog rękopisów staropolskich Biblioteki Kórnickiej XVI-XVIII w., oprac. R. Marciniak, M. Muszyński, J. Wiesiołowski, Wrocław 1985, s. VII. 
dopodobne rozbicie mnóstwa catości archiwalnych $i$ kolekcyj bibljotecznych ${ }^{64}$. Monumentalną pracą dokumentującą zbiory rękopiśmienne zgromadzone w polskich bibliotekach naukowych oraz muzeach stanowi nadal praca D. Kamolowej i T. Sieniatyckiej Zbiory rękopisów w bibliotekach i muzeach $w$ Polsce $e^{65}$. W drugim wydaniu znacznie rozszerzono opracowane hasła, niektóre biblioteki zostały opracowane na nowo. Istotnym elementem publikacji z 2003 roku jest uwzględnienie posiadania przez biblioteki katalogów drukowanych rękopisów $w^{66}$.

\section{Abstract \\ Development methods of drawing Polish manuscripts sets up on the example of catalogues printed}

The article analyses 91 manuscript catalogues of major scientific polish libraries that contain over 15000 manuscripts. An analysis of the article reference material provides an explicit and unambiguous account of catalogue creation, manuscript study and processing, construction of additional support apparatus as well as the nature of catalogue author introductions. Printed catalogues of manuscripts within scientific libraries usually begin with an author introduction (foreword) that epitomizes: the subject area, chronology of catalogue, details of library history including foundation and manuscript collection process.

Frequently, the catalogue introduction is the main and sometimes only source of information regarding the history of the book collection and library itself. The most relevant section of the catalogue consists of a description of individual manuscripts. These contain the following: signature - formal description, description of manuscript content and additional library apparatus including index of names, index of places and items, ordered topographical index etc. The rules outlining the description of manuscript collections printed after 1955 can be found in "Wytyczne opracowania rękopisów bibliotek polskich” - B. Horodyski, H. Więckowska.

${ }^{64}$ K. Buczek, Zbiory rękopisów polskich bibliotek naukowych. Księga referatów IV Zjazdu Bibliotekarzy Polskich, Warszawa 1936, s. 70-72.

${ }_{65}$ D. Kamolowa, K. Muszyńska, Zbiory rękopisów w bibliotekach i muzeach $w$ Polsce, Warszawa 1988, wyd. 2, Warszawa 2003.

${ }^{66}$ Informacje o wydaniach katalogów rękopisów drukowanych bibliotek naukowych pozyskano z publikacji - D. Kamolowa, K. Muszyńska, Zbiory rękopisów w bibliotekach i muzeach w Polsce, Warszawa 2003. 